This is an author produced version of a paper published in Scandinavian Journal of Forest Research. This paper has been peer-reviewed and is proof-corrected, but does not include the journal pagination.

Citation for the published paper:

Stryamets, N., Elbakidze, M. \& Angelstam, P. (2011) Role of non-wood forest products for local livelihoods in countries with transition and market economies: case studies in Ukraine and Sweden. Scandinavian Journal of Forest Research. iFirst article, pp 1-14.

http://dx.doi.org/10.1080/02827581.2011.629622

Access to the published version may require journal subscription.

Published with permission from: Taylor \& Francis

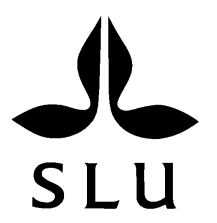

Epsilon Open Archive http://epsilon.slu.se 


\title{
Role of non-wood forest products for local livelihoods in countries with transition and market economies: case studies in Ukraine and Sweden
}

\author{
Nataliya Stryamets (1, 2), Marine Elbakidze (2), Per Angelstam (2) \\ 1. Ukrainian National Forestry University, Forestry Faculty, Generala Chuprynky 103, \\ Lviv, Ukraine. \\ 2. Swedish University of Agricultural Sciences, Faculty of Forest Sciences, School for \\ Forest Management, SE 73921 Skinnskatteberg, Sweden.
}

\begin{abstract}
The role of non-wood forest products (NWFPs) in local economies differ in time and space. We analysed Ukrainian and Swedish national policies and management rules related to the use of NWFPs, and described how different forest stakeholders utilised NWFPs in rural areas in Ukraine and Sweden. In total we interviewed 114 local forest stakeholders in one rural region's settlements in both countries. The topics for the field study were (1) the reasons and amounts of NWFPs harvested by different forest user categories; (2) traditional practices of NWFP use, including harvesting methods and (3) how these practices have changed over the past decades. At the national level, both countries allowed the utilisation of most NWFPs, did not regulate the use, and did not include NWFPs into forest management plans. In both case studies, historical use of NWFPs was intensive. This use remained important in Ukraine, but not in Sweden. Due to difficult economic transition in Ukraine, use of NWFPs by locals has increased. While hunting as a tradition was more popular in the Swedish case study, recreational use of forest was popular in both case studies. Finally, we discuss the role of NWFPs in countries with transition and market economies, and the extent to which the countries support sustainable use of NWFPs.
\end{abstract}

\section{Introduction}

Globally, forests provide wood and a large variety of non-wood forest products (NWFPs) as a resource base for economic and rural development. NWFPs are defined as goods of biological origin other than wood, derived from forests, wooded lands and trees outside forests (FAO, 1999). Use of NWFPs has a long history as an important component for the livelihoods of people living in and in the vicinity of woodland and forest landscapes (e.g., Wong et al. 2001; Saastamoinen, 1999; Saastamoinen et al., 2000). NWFPs were one of the first sources of food, medicine, fibre, energy and other resources that sustained local communities. Descriptions of wild fruits have been found in the ruins of Babylon, Carthage, Athens and Rome (Petrova, 1986). Among the Greeks and Romans, there is a rather comprehensive description of NWFP in the works of Theophrastus, Cato the Elder, Hippocrates, Pliniya Elder (Terletskyy, 1985; Petrova, 1986).

Estimates indicate that $80 \%$ of the population in developing countries uses NWFPs to meet some of their nutritional needs and provide herbal medicine (Ryabchuk, 1996; FAO, 1999; Malyk 2006). Also in developed countries, where locals were dependent on NWFPs in the past, they often continue to provide important material and cultural resources for local households (Kardell, 1980; Janse \& Ottitsch, 2005). During recent decades, NWFPs have attracted considerable interest as an important component of sustainable forest management (SFM) policies (MCPFE, 2003a; MCPFE, 2003b; The Montréal process, 2009) and governance (e.g., Laird et al. 2010). There have been many efforts to combine industrial timber production with multiple uses of forests to increase different forest values for users, owners and local communities that depend on them. A number of studies demonstrate the potential of using NWFPs from natural 
(Godoy et al., 2000; Campos et al, 2005) and managed forests (Campos et al, 2005) for rural development of forest dependent communities.

Policy-makers, governmental and non-governmental organisations involved with rural development make different efforts to promote new modes of forest use to support traditional livelihood strategies (Hyde \& Köhlin, 2000; Nijnik \& Oskam, 2004; Nijnik \& van Kooten, 2006). However, the role of NWFPs for livelihoods of local communities in different societal contexts has not been compared in detail. In particular there is a lack of comparative studies about the role of NWFPs supporting livelihoods in rural areas in countries with different economic and social-cultural conditions. Ukraine and Sweden are two European countries in different phases of economic development with differing systems of nature resource governance and management. Ukraine is in a transition from planned Socialist system to market economy, which has been accompanied by political and economic crisis during the last decade (Nijnik \& Oskam, 2004; Nijnik \& van Kooten, 2006; Angelstam \&Elbakidze, 2009; Elbakidze \& Angelstam, 2009). During this difficult transition period, many people in remote forestdependent communities re-adopted their traditional subsistence farming and forest use to maintain their livelihoods (Bihun, 2005; Elbakidze \& Angelstam, 2007). NWFPs thus continue to be a part of the social fabric and livelihood (Bihun, 2005; Malyk, 2006). By contrast, Sweden has a well developed market economy. Here, urbanisation has increased disconnection between people and natural resources and reduced use of NWFPs (Kardell, 1980). Differences in country developments are reflected in the perception of low rates of corruption where Sweden ranks number 1 and Ukraine 134 of 158 countries surveyed (Zinnbauer et al., 2009), and regarding democracy, where Sweden ranks number 4 and Ukraine ranks 67 of 167 (The Economist, 2010). Nevertheless, intensification and modernization of natural resource use has resulted in depopulation of rural areas in both countries (Bryden \& Hart, 2004; Government Offices of Sweden, 2008).

To promote sustainability of forests on national as well as regional and local levels, both Ukraine and Sweden have joined processes of developing and implementing SFM principles. The strategic objectives of the Ukrainian national forest legislation are oriented towards sustained yield forestry, maintenance of forest biodiversity and socio-cultural values of forests (Anon., 2006). Ukraine has signed the 17 resolutions of the Ministerial Conferences on Protection of Forests in Europe (Anon., 2004). Sweden has a long history of gradual development of policies aiming at sustainability in terms of sustained wood yield (e.g., Hagner, 2005; Enander, 2007) and biodiversity conservation (SEPA, 2005). The Swedish national forest and environmental policy objectives include maintenance a sustained wood production capacity and conservation of viable populations of all naturally occurring species (Swedish Forestry Act, 1993; Boström, 2002; Eriksson \& Hammer, 2006). Recent forest policy documents (e.g., Anon., 2007/08) confirm this development and stress focus on sustained and increased wood production, as well as ecological and socio-cultural sustainability.

The aim of this study is to analyse the role of NWFPs for local level forest stakeholders in rural communities in Ukraine and Sweden in order to define the contribution of these resources to local livelihoods in countries with different economic and social-cultural conditions and systems of natural resource governance and management. First, we analyse international and national policy documents concerning NWFPs as a component of SFM as well as national and regional management regulations related to use of NWFPs in the two countries. Second, we present the results of interviews with local forest stakeholders in case study areas in Ukraine and Sweden concerning the reasons for NWFPs collection, amount of harvested NWFPs by local forest stakeholders, and existing practices of NWFP utilization. Finally, we discuss the 
role of NWFPs in countries with transition and market economies, and the extent to which these two countries support the sustainable use of NWFPs.

\section{Materials and Methods}

\section{Study areas}

\section{Roztochya in western Ukraine}

The Ukrainian Roztochya area is located in the temperate lowland forest ecoregion in western Ukraine, and covers an area of $992 \mathrm{sq}$. km. It is an important green infrastructure corridor across the Eastern European Union border. The Roztochya forest landscapes have high natural and cultural values (Stryamets \& Danchuk, 2007). Forests cover about $44 \%$ of the total area, and the rest is made up by cultural woodland landscapes, agricultural land and villages. The forest types are very diverse ranging from dry sites with Scots pine [Pinus sylvestris (L.)] to mesic sites with beech [Fagus silvatica (L.)], and wet sites with ash [Fraxinus excelsior (L.)] and black alder [Alnus glutinosa (L.)] (Stryamets \& Ferenc, 1999; Stryamets \& Danchuk, 2007). The villages are generally traditional with a gradient from houses with gardens, and in-fields used for growing food or as orchards, to fields and meadows (e.g., Elbakidze \& Angelstam 2009).

The area hosts many different forest stakeholders, which have the right to use forest resources for commercial, nature conservation and domestic purposes. The population density is about 80 persons per sq. km (Anon., 2008b). There are 120 settlements in Roztochya with 59,922 inhabitants and 8 state forest management units, which are under the management of different governmental organizations including the State Forestry Committee, Ministry of Defence and Ministry of Agriculture, Ministry of Education and Science. In addition, there are two protected areas, Yavoriv National Nature Park and Roztochya Strict Protected Reserve, which are under the management of Ministry of Environmental Protection and Ministry of Education and Science, respectively.

During the Soviet period (1917-1991), sulphur mining formed the base for the economy in the Roztochya region, and more than 20,000 people, locals and incomers, were employed by the mining industry. In the villages within the region, collective agricultural farms were the main employers for local people. After the collapse of the Soviet Union in 1991, the mining industry was closed and, as a result, people lost employment. The collective farms were reorganized into small-scale farms or were abandoned due to the new political and economic development towards market economy. Unemployment is still the main problem in the area.

\section{Småland in southern Sweden}

The Swedish study area is located in the central part of Småland, an upland area in southern Sweden, the core of which forms the southernmost larger island of boreal forest in Sweden and is dominated by Scots pine and Norway spruce [Picea abies (L.) Karst.]. Toward the south, there is a gradual transition to hemi-boreal and the northernmost part of the temperate lowland deciduous forests with beech. Today's forest-dominated landscape has a very long history of human use based on animal husbandry and farming (Lagerås, 1996, 2007). The best soils were cleared for agricultural use, a process that started 6200-3800 BC in this part of Sweden (Johansson, 1999). Already more than 2000 years ago (Johansson, 1999), human use developed to a traditional village system that shaped over the years a cultural landscape with high natural and cultural values (Berglund et al., 2002). Fenced villages with gardens and infields with crops and meadows were surrounded by grazed forests. During the second 
half of the 20th century, grazed mixed deciduous and coniferous forests were transformed into production forests by introduction of Norway spruce plantations and gradual development of sustained yield forestry (Björkman, 1996, Bradshaw et al., 2000).

Private landowners are key local stakeholders in the social system governing the economic use of forest resources. Non-industrial private forest owners own 80-85\% of the forests in the study area (The Swedish Forest Agency, 2010). The other main forest owners are the state forest company Sveaskog, municipalities, and the Swedish Church. The Swedish study area encompassed 22 parishes and towns with a total area of 1792 sq. km, and an average population density of 53 persons per sq. km, but with only 13 persons per sq. $\mathrm{km}$ in rural parishes without towns. The population trend is negative, especially in rural areas which host $26 \%$ of the population (Anon., 2003). Nevertheless, unemployment rates are lower than the Swedish average.

\section{Methods}

We analysed international and national forest policy documents related to NWFPs as a component of SFM and management regulations concerning use of NWFPs in Ukraine and Sweden. We also conducted qualitative semi-structured interviews (Glasser \& Strauss, 1967; Ryen, 2004; Kvale, 2007; Kvale \& Brinkman, 2008) with local forest stakeholders in our study areas in spring and summer 2010. An interview manual was developed that included a mixture of open-ended and closed questions. The collected data contained information about: (1) the type of harvested NWFPs; (2) the volume of collected NWFPs and methods, (3) methods of utilization, including traditional practices, and (4) information about the collector (age, gender and community background). Each interviewee was given full freedom to talk about the subject. The interviews were taken with different groups of stakeholders including villagers, managers of forest enterprises and managers of protected areas in our study areas. The interviews with local people were taken in settlements with different population size located at different distances to forest. The litre estimates of mushrooms were subsequently converted into kilograms for the purposes of this study.

In total 54 interviews were taken in 26 settlements and towns in the Ukrainian Roztochya and 60 interviews in 36 settlements and towns in the Swedish Småland. The interviews lasted from 20 to 60 minutes. All interviews were digitally recorded, transcribed and analyzed for emergent themes and consistency with the existing literature relative to NWFP utilization and practice. The gender distribution of the sample in Roztochya was 55\% females and 45\% males. The Ukrainian population gender distribution was 54\% women and 46\% men (Anon., 2008b). The gender distribution of the sample in Småland was 53\% females and $47 \%$ males. The gender ration of the Swedish population is 50\% women and 50\% men (Statistics of Sweden, 2011). The survey differentiated among four categories of age. In Småland, 18\% of the respondents were $16-25$ years old, $42 \%$ were $26-50$ years old, $25 \%$ were $51-65$ years old, and $15 \%$ were 66 or older. In Roztochya, $6 \%$ of the respondents were 16-25 years old, $43 \%$ were $26-50$ years old, $36 \%$ were $51-65$ years old, and $15 \%$ were 66 or older.

\section{Results}

Analysis of policy documents and management rules

Policies at global, Pan-European and national levels clearly pronounce the importance of NWFP as a relevant attribute to rural development and natural resource utilization (Chandrasekharan, 1993, 1995; Janse \& Ottitsch, 2005; FAO, 2002; Ticktin 2004). In 1992, at the United Nations Conference on Environment and Development (UNCED) in Rio de Janeiro, it was declared that the promotion and use of NWFPs is an important 
part of sustainable development (UNCED, 1992). SFM is one of the directions toward sustainable development as a societal process and sustainability as an outcome on the ground (MCPFE, 1993; Løyche Wilchie et al., 2003). SFM is supported by different international processes and organizations, taking into account the specific forest condition in different parts the world (McDonald \& Lane 2004; Rametsteiner \& Mayer, 2004; ITTO, 2005; The Montréal Process, 2007). Pan-European criteria and indicators for SFM have been developed by the Ministerial Conferences on Protection of Forest in Europe (MCPFE) (e.g., MCPFE, 1993; 1995; 1998a; 2001) and by the Working Group on Criteria and Indicators for the Conservation and Sustainable Management of Temperate and Boreal Forests (The Montréal Process, 2007).

Sustainable management of NWFPs is clearly a component of SFM initiatives. Compared to the Helsinki resolution (1993), the interest in and demand for NWFPs has increased and been encouraged over time (MCPFE, 1993; 1998). According to Resolution L2, criterion 3 is to maintain and encourage productive functions of forests, which include both wood and non-wood products. The descriptive indicators of this criterion require the development of management plans for NWFPs (MCPFE, 1998). At the 4th Ministerial conference in Vienna, the criteria and indicators of SFM were changed with the aim to increase benefits of rural livelihoods from forests (MCPFE, 2003a; Rametsteiner \& Mayer 2004). The Vienna Resolution 2 highlighted the importance of the promoting use of NWFPs (MCPFE, 2003b). Both Ukraine and Sweden have joined the MCPFE process for SFM development in Europe

According to FAO (1999), NWFPs are grouped into 16 categories (Table 1). Plant non-wood forest products are classified into 8 categories: (1) food; (2) fodder; (3) raw material for medicine and aromatic products; (4) colorants and dyes; (5) utensils, handicrafts and construction; (6) ornamental plants; (7) exudates and (8) other plants products. Animal non-wood forest products are grouped into the next 8 categories: (9) living animals; (10) hides, skins and trophies; (11) wild honey and bee-wax; (12) bush meat; (13) raw material for medicines; (14) raw material for colorants; (15) other edible animal products and (16) other non-edible animal products.

In Ukraine, the main trend in forest policy development has been to provide a balance between the conservation of forest ecosystems and sustainable multi-purpose use of forests. Forest management should be conducted according to the Forest Code (2006) and within the framework defined by the State Programme "Forest of Ukraine in 2010-2015” (Anon., 2009). The Forest Code of Ukraine (2006) has several articles about "secondary forest products", which contain information about NWFPs. There is, however, neither full explanation what kinds of non-wood products that are included into this category, nor how they should be managed. The direct use of NWFPs includes harvesting of hay, grazing, picking wild fruits, nuts, mushrooms, berries and medical herbs (Anon., 2006). Hunting is not included into the NWFPs definition and regulated by law in Ukraine (Anon., 2000). The collection of NWFP for private needs in state and community forests is free for everyone. According to Forest Code of Ukraine, in private forests, local people have to secure a permit for harvesting of NWFPs from the owner (Anon., 2006). Private ownership for forests had not developed yet in Ukraine. Collection of NWFPs for sale is called "special use of NWFPs” (Anon., 2006). Commercial collection of NWFPs by a private person or a company requires a special permit and the collector has to pay to the forest user (Anon., 2006).

The State Program “Forests of Ukraine during 2010-2015” (Anon., 2009) is based on the MCPFE criteria and indicators and defines the guidelines for forest management towards SFM. The state forestry enterprises are obliged to protect forest wood and non-wood resources from illegal or harmful collection by people. Collection of secondary forest products (NWFPs) in managed forests should be done without harming forest ecosystems (Anon., 1996). Medical herbs and mushrooms which are 
Table 1. The categories of non-wood forest products (NWFPs) harvested and utilized in the Roztochya region (Ukraine) and Småland (Sweden)

\begin{tabular}{|c|c|c|c|c|c|}
\hline & \multirow[t]{2}{*}{ NWFPs category } & \multicolumn{2}{|c|}{ Roztochya region in Ukraine } & \multicolumn{2}{|c|}{ Småland in Sweden } \\
\hline & & \multirow{2}{*}{\multicolumn{3}{|c|}{$\begin{array}{l}\text { Number of species } \\
\text { Plants }\end{array}$}} & \multirow[t]{2}{*}{ Number of species } \\
\hline & & & & & \\
\hline 1 & Food & Berries & $4(8)$ & Berries & $2(3)$ \\
\hline & & Mushrooms & $5(13)$ & Mushrooms & $2(8)$ \\
\hline & & Birch juice & 1 & & \\
\hline 2 & Fodder & No & 0 & No & 0 \\
\hline 3 & $\begin{array}{l}\text { Raw material for medicine and aromatic } \\
\text { products }\end{array}$ & Medical herbs & 12 & No & 0 \\
\hline 4 & Colorants and dyes & No & 0 & Mushrooms & 4 \\
\hline 5 & Utensils, handicrafts and construction & $\begin{array}{l}\text { Salix } \\
\text { Juniperys }\end{array}$ & 2 & No & 0 \\
\hline 6 & Ornamental plants & $\begin{array}{l}\text { Salix, Vinca minor L., } \\
\text { Viburnum opulus L. }\end{array}$ & 3 & No & 0 \\
\hline 7 & Exudates & No & 0 & No & 0 \\
\hline 8 & Other plants products & cattle grazing, hay & Yes & No & 0 \\
\hline \multicolumn{6}{|c|}{ Animal products } \\
\hline 9 & Living animals & No & 0 & No & 0 \\
\hline 10 & Hides, skins and trophies & Skins (up to $10 \%$ ) & 3 & Skins, trophies & $4(7)$ \\
\hline 11 & Wild honey and bee-wax & Beekeeping & 1 & No & 0 \\
\hline 12 & Bush meat & Hare, roe deer, wild boar & 3 & $\begin{array}{l}\text { Moose, roe deer, wild boar, } \\
\text { hare }\end{array}$ & \\
\hline 13 & Raw material for medicines & Badger fat & 1 & No & 0 \\
\hline 14 & Raw material for colorants & No & 0 & No & 0 \\
\hline 15 & Other edible animal products & No & 0 & No & 0 \\
\hline 16 & Other non-edible animal product & No & 0 & No & 0 \\
\hline
\end{tabular}


Table 2. The harvested non-wood forest products (NWFPs) by local stakeholders in Roztochya (Ukraine) and Småland (Sweden)

\begin{tabular}{|c|c|c|c|c|c|c|}
\hline \multirow[b]{2}{*}{ Species } & \multicolumn{3}{|c|}{ Roztochya (Ukraine) } & \multicolumn{3}{|c|}{ Småland (Sweden) } \\
\hline & Part collected & $\begin{array}{l}\text { \% respondents } \\
\text { who collected }\end{array}$ & $\begin{array}{l}\text { Mean quantity per } \\
\text { season, litres }\end{array}$ & Part collected & $\begin{array}{l}\text { \%respondents who } \\
\text { collected, \% }\end{array}$ & $\begin{array}{l}\text { Mean quantity per } \\
\text { season, litres or kg }\end{array}$ \\
\hline \multicolumn{7}{|l|}{ Plant } \\
\hline Fragaria vesca L., & Berries & 52 & 2 & Berries & 2 & 2 \\
\hline Vaccinium myrtillus L., & Berries & 85 & 10 & Berries & 56 & $2-5$ \\
\hline Rubus caesius L. & Berries & 65 & 10 & Berries & 0 & No \\
\hline Rubus idaeus L. & Berries & 44 & 6 & Berries & 0 & No \\
\hline Vaccinium vitis-idaea L. & Berries & 8 & 1 & Berries & 53 & $1-5$ \\
\hline Mushrooms (all types in total) & Mushroom & 85 & $4 \mathrm{~kg}$ & Mushroom & 62 & $1-2$ \\
\hline Viburnum opulus L. & Berries & $\sim 40$ & Small amount & No & No & No \\
\hline Sorbus aucuparia L. & Berries & $\sim 40$ & Small amount & No & No & No \\
\hline Fragaria vesca L. & Leaves, flowers & $\sim 40$ & Small amount & No & No & No \\
\hline Urtica dioica L. & Leaves & $\sim 40$ & Small amount & No & No & No \\
\hline Rosa canina L. & Fruits & $\sim 30$ & Small amount & No & No & No \\
\hline \multicolumn{7}{|l|}{ Animal } \\
\hline Vulpes vulpes L. & Skin & $\sim 10$ & 1 & Skin & 40 & $\mathrm{D}$ \\
\hline Sus scrofa L. & Meat & $\sim 10$ & 1 & Meat & 40 & $\mathrm{D}$ \\
\hline Lepus timidus L. & Skin, meat & $\sim 10$ & 1 & Skin, meat & 40 & $\mathrm{D}$ \\
\hline Capreolus capreolus L. & Meat & $\sim 10$ & 1 & Meat & 40 & $\mathrm{D}$ \\
\hline
\end{tabular}


listed in the Red Data Book of Ukraine (Anon., 1996; Red Data Book of Ukraine, 2009) are not allowed for harvesting, not even parts of the plants or mushrooms may be harvested. There is a list of species that are endangered but may be collected under strict guidelines. For these, a special ticket for picking must be purchased. Harvesting of plant parts and berries is allowed if the berries comprise more than $10 \%$ of the ground cover in the forest and the ground cover of medical herbs more than 5\% (Anon., 1996). The requirements concerning harvesting of medical herbs also include regulations about the parts of herbs which could be collected. For example, less than $10 \%$ of roots and $40 \%$ of leaves are allowed to harvest.

There are many restrictions for harvesting of NWFPs from protected forests in Ukraine. It is forbidden to collect NWFPs in strictly protected reserves (Anon., 1992). In national nature parks, collection of NWFPs is prohibited in the management zone of strict nature protection. However, it is allowed in the management zones where tourist facilities are located and where local people conduct their land use activities.

There are restrictions in Ukraine related to hunting, and the hunting organizations are responsible for providing licenses to hunters. Hunting organizations also protect animals from illegal hunting and take care of game during the winter season by feeding wild animals. Hunting of different game species is allowed during specific seasons of the year (Anon., 2000). It is forbidden to hunt Red Data Book listed species in Ukraine (Red Data Book of Ukraine, 2009).

The Swedish Forestry Act from 1979, which regulates the forest resource use, does not include any kind of direct information about NWFPs. According to this Act, after its subsequent major forest policy revision, the government established that wood production and environmental goals are of equal importance for Sweden's forests (Anon., 1992/1993). However, in the most recent forest policy, berries and mushrooms are mentioned under the heading "social considerations", and hunting is described both as a NWFP and a tourist attraction (Anon., 2007/08). The Swedish Environmental Code, which was adopted in 1998 and amended in 2000, declares the promotion of sustainable development with healthy environment for present and future generations but provides no specific explanation about NWFPs (SEPA, 2005). Recreation should be done without harming the forest ecosystems.

As in all Nordic countries, the right of public access to all forests or "Right of Public Access", or freedom to roam, ("allemansrätt" in Swedish) is a customary right in Sweden. Public access rights arose during the Middle Ages, allowing all people to use forests for recreation and collection of flowers, berries, mushrooms and medical herbs. However, some plants and lichens are protected and collection of them is thus prohibited. All species of orchids, for example, are under such protection (SEPA, 2009). Special rules towards nature conservation and utilization of NWFPs in strict nature reserves, national parks and historical sites have been established (SEPA, 2009). These rules are different in different areas. As an example, in Garphyttan National park it is forbidden to collect plants, but it is permitted to collect berries and mushrooms. However, in Söderåsen National Park it is forbidden to collect lichens, food mushrooms, moss and dig up plants (SEPA, 2009). Private forests are also open for local people and tourists, be they domestic or foreign. Large-scale commercial berry picking is permitted (SEPA, 2009). In Sweden, hunting rights are linked to land ownership and landowners may hunt themselves or sell their hunting rights. While there are no restrictions to harvest levels for small game, for big game such as moose and large carnivores (brown bear [Ursus arctos (L.)], lynx [Lynx lynx (L.)] and wolf [Canis lupus (L.)]), quota are determined at regional levels (Anon, 1987).

Types and amount of collected NWFPs 
The first documents that provide information about the use of medical herbs in Ukraine are the chronicles of "Povist Vremennyh lit" and "Galucko-Volynskyi litopys" (Kruglyakov, 1991; Ryabchuk, 1996). Berries and mushrooms were important sources of food and medicine for centuries in Ukraine (Ryabchuk, 1996). In the $18^{\text {th }}$ century, in Western Ukraine, local people actively used traditional medicine based on medical herbs (Komendar, 1971). According to various sources, more than 200 species of forest plants and mushrooms have been used in traditional medicine by local people (Komendar, 1971; Yelin et al., 1987; Kruglyakov, 1991;Ryabchuk, 1996). Before the First World War, income from the mushroom export was larger than the income from timber export in whole Ukraine (Terletskyy, 1985). Under the Soviet Union (19171991), NWFPs were used actively both by local populations and by forestry enterprises (Telishevskyy, 1972; Terletskyy, 1985; Petrova, 1986; Kruglyakov, 1991). For example, the state forestry enterprises had a plan concerning the amount of NWFPs that they had to harvest in the managed forests (Kruglyakov, 1991). A total of 6.5 to 9 tons of mushrooms and from 6.2 to 7.9 tons of medicinal raw materials were harvested annually in Ukraine by the state forestry enterprises (Telishevskyy, 1972; Terletskyy, 1985).

In our Ukrainian study area, all interviewees collected wild berries. Around $60 \%$ of local people collected at least 4 different species of berries, namely wild strawberries [Fragaria vesca (L.)], blueberries [Vaccinium myrtillus (L.)], blackberries [Rubus caesius (L.)] and raspberries [Rubus idaeus (L.)]. The maximum number of collected species was eight, i.e., including also lingonberries [Vaccinium vitis-idaea (L.)], guelder rose [Viburnum opulus (L.)], common hawthorn [Crataegus monogyna (Jacq.)] and rowan [Sorbus aucuparia (L.)]. In 96\% of the studied settlements, people also collected mushrooms. The most popular mushrooms in the region were penny bun or cep [Boletus edulis (Bull. ex Fr.)], red-capped scaber stalk [Leccinum aurantiacum (Bull. ex Fr.) S. F. Gray)], honey fungus [Armillaria mellea ((Vahl. ex Fr.) Kumm.)] and birch bolete (Leccinum scabrum (Bull.Gray)] (Table 2). Respondents mentioned that they liked to collect sheep's head [Grifola frondosa ((Dicks.) Gray)], a Red Book listed species of mushroom in Ukraine (Red Data Book of Ukraine, 1996). Respondents reported that knowledge about where, how and what species of mushrooms should be collected were passed from parents to children. Additionally, in spring, the villagers collected birch sap for personal needs, as “a healthy and tasty drink".

Collection of medical herbs was popular. On average, five species of medical herbs in forests were collected by each household, e.g., guelder rose, rowan, wild strawberries, common nettle [Urtica dioica (L.)] and dog rose [Rosa canina (L.)] In one village, people collected more than 12 species of plants. People used medical herbs as a tea and for different kinds of tinctures for support or promote health. Different parts of the plants were used as well, such as the flowers of linden [Tilia cordata (Mill.)], the buds of birch [Betula pendula (Roth.)] or leaves of common nettle. Local people used the forest also for cattle grazing and for gathering of fresh grass and hay-making.

Beekeeping was also present in the region, but not as a widespread activity (Table 1).

Each household collected NWFPs for domestic needs and some households for sale to generate cash income. For domestic purposes, on average, each studied household harvested 10 litres of blueberries, 10 litres of blackberries, 6 litres of raspberries and 1-2 litres of wild strawberries annually. Additionally, 2 to more than 200 litres blueberries were sold annually. The volume of the collected mushroom for personal needs differed greatly among households, from 3-4 kg to almost $130 \mathrm{~kg}$ of fresh mushrooms. The medical herbs were consumed in small quantities. Approximately 3 litres of birch sap was consumed per household. 
Hunting was not popular among Ukrainian study participants. Respondents said that the prices for licenses were too high, and that there was not much wild game to hunt. The average price of a hunting license was $300 \mathrm{UAH}$, or approximately 30 Euros, for one hunting season. The respondents stated that not more then $10 \%$ of local people in the region hunted regularly. Most hunters came from the larger towns and cities near Roztochya. These hunter typically hunted ducks [Anas platyrhynchos (L.)], hare [Lepus timidus (L.)], fox [Vulpes vulpes (L.)], roe deer [Capreolus capreolus (L.)] and wild boar [Sus scrofa (L.)].

Distances from villages to the forest ranged from just a few meters to $20 \mathrm{~km}$. As a rule, due to absence of cars or because it was expensive to go by car, villagers went to the forests on foot, even if the distance was more than $10 \mathrm{~km}$. On average, local people spent 3-4 hours per day in the forest during a season, and some respondents spent whole days in the forests to harvest NWFPs. According to the interviews during NWFP harvest season, villagers went to the forests every day. However, respondents who had jobs or farms spent less time in the forest for gathering NWFPs. Local people collected berries by hand. They were familiar with tools for gathering berries, however, they refused to use them because they argued that the berries would be smashed and they would be hard to sell. Some pointed out that it was enjoyable to be out in the forest, like a hobby.

As key local forest stakeholders, the state forestry enterprises had decreased the amount of extracted NWFPs, except hunting, from the forests in comparison with the extraction rates under the Soviet system. According to (Terletskyy, 1985), during the Soviet time, the amount of harvested berries per year was approximately 16,000 tons depending on a years yield; mushrooms varied from 550 to 3500 tons, birch sap from 40,000 to 50,000 tons and 1175 tons of medical herbs. NWFP collection was regulated by the state plan prescribed to each of the forestry enterprises. Interviews with the directors of the forest enterprises in the study area indicated that none of eight forestry enterprises collected NWFPs any more. The primary reason for this was lack of profitability due to increased costs for fuel and labour that were higher than the income from selling the NWFPs, since the transition to market economy. The local industries that cooperated in with forestry enterprises to produce value-added products from raw NWFPs in the past were closed.

\section{Småland (Sweden)}

In Sweden, historically, around 35 native varieties of wild berries, fruits and other edible plants were used as a source of food (Kardell, 1980). All these species had domestic importance until the second half of $19^{\text {th }}$ century. When the domestic railroad network was extended, berries gained an economic value for the rural population. However, mushrooms were not used by local populations in Sweden. According to Kardell (1980), the custom of eating mushrooms was imported from France and adopted by the Swedish nobility, but not by rural people. For the Småland study region, Nordström et al. (1989), Nordmark (1997) and Johansson (1999) described the wide use of medicinal plants until urbanisation began in the early $20^{\text {th }}$ century. As a sign of the past use of lingonberry, the "red gold of the forest," these berries were still important for the sense of place in the Småland region according to brochures for tourists (Källberg, 2007), and the regional trains were called "lingonberry trains" (Swe: krösatåg) since 1985. The term stems from the time of a "lingonberry boom" (Swe: lingonruschen) in Småland, when berries were exported to Germany at the end of the $19^{\text {th }}$ until 1914 when WW1 began. At present, in the Swedish study area, almost $80 \%$ of interviewed local people collected berries. In $58 \%$ of the studied settlements, local people collected 2 species of berries, such as blueberries and lingonberries, which were also the most popular berries in the region. The maximum number of collected berries 
was 3 species, blueberries, lingonberries and blackberries, in $8 \%$ of the studied settlements.

The amount of collected berries varied from 0.5 to 90 litres, and on average it was 2-5 litres of blueberries per family. The maximum amount of berries was 90 litres of blueberries and 90 litres of lingonberries The most popular harvested mushrooms in Småland were chanterelle [Chanterel cantharellus ((L.), Murrill)] and funnel chanterelle [Craterellus tubaeformis ((Fr.) Quel)]. The maximum number of mushrooms species was eight, and was collected only by one person who used it to produce colour pigments for clothes. Local people did not collect any medical herbs in this region. In the interviews, respondents often suggested that they did not have enough knowledge about the species of medical herbs or mushrooms and their uses. Besides berries and mushrooms, people collected flowers for decoration. The prevailing forest use was recreational activities. Respondents pointed that they found the forest experience rejuvenating and energizing.

In our Swedish study area, hunting was a very popular activity among the villagers. More than $40 \%$ of respondents stated that at least one member of their family was a hunter. In Sweden, the forest owners have rights to hunt in their own forests without payment for hunting, except big mammals, such as moose [Alces alces (L.)], lynx and bear. There were also hunting management associations which control the hunting process. Some respondents said that if they owned the forest, they would hunt there. The reasons for hunting were both traditions and enjoyment. The most popular species to hunt were moose, roe deer, wild boar, hare and ducks.

Interviews with representatives of the state forest company Sveaskog Co. in Småland indicated that there was no collection of any kind of NWFPs by the company. However, Sveaskog Co. provided land for rent to hunters.

In Småland the shortest reported distance to the forest from the household was 10 meters, the range of the distance was $0.01 \mathrm{~km}$ to $15 \mathrm{~km}$. During the berry and mushroom seasons villagers went to the forests as usually once per week. The respondents who owned forest spent more time in the forest due to their responsibility to take care of their forest. In Småland, more than $65 \%$ of respondents were using equipment to collect berries and $35 \%$ of respondents were collecting small amount of berries by hand.

\section{Utilization of NWFPs}

\section{Roztochya (Ukraine)}

The majority of villagers collected berries and mushrooms for sale and for domestic consumption. The berries collected for sale were wild strawberries, blueberries, blackberries and raspberries. Mushrooms collected for sale included penny bun or cep, red-capped scaber stalk and honey fungus. Some interviewees reported that they earned more than 3,000 UAH (approximately 300 EUR, equivalent to two monthly salaries in rural areas) per season from selling berries. The price for one litre of blueberries was on average 10-15 UAH, which means that people collected and sold approximately 200 litres of berries. The price for one litre of wild strawberries was around $50 \mathrm{UAH}$ (approx. 5 EUR), one kilogram of penny bun or cep was 60 UAH (approx. 6 EUR). The respondents did not like to talk about the amount of money that they could earn from selling mushrooms and berries, but they pointed out that they could live on that money for several months. One of the common statements was: "Because people don't have jobs they have to find ways to earn money. Young, middle aged and old people pick berries and mushrooms".

Local people sold berries and mushrooms in markets in the nearest cities and towns, and along the main roads in the region. Interviewees mentioned that one could 
earn 100 UAH (approx. 10 EUR) per day, which was more than the mean daily labour payment in rural areas. The distance to markets was 2 to $60 \mathrm{~km}$. In villages located close to the border with Poland local people sold berries (mostly blueberries) to foreign companies, which transported berries to Poland to produce value-added products. Respondents mentioned that it was easy to sell to the Polish companies, because they bought all collected berries. The average price for one litre of blueberries was $10 \mathrm{UAH}$ (approx. 1 EUR).

Local people also collected NWFPs for own needs. All respondents mentioned that it was a tradition to cook dishes including NWFP for Christmas. About $26 \%$ of respondents mentioned that it was important to pick up mushrooms for religious holidays, which included traditional meals prepared with wild mushrooms. Observation of this tradition was important even for respondents for whom collection of mushrooms was not an economic or subsistence activity. People collected berries for their kids because it was a clean and healthy product. One respondent stated that "I know that one should eat 3 litres of blueberries and the same amount of wild strawberries per season; then one would have enough vitamins for the whole year." Some people stated that picking berries and mushrooms was like a hobby. Nearly $90 \%$ of the respondents said that parents had taught them to pick berries and mushrooms; however, some stated that nowadays kids would rather spend time with computers instead of going to the forest. The respondents that hunted mentioned that they used meat for food.

A majority of the respondents mentioned that the collection of NWFPs had became more intensive compared to 20-25 years ago. One of the reasons was that, during the Soviet period, people had jobs at the collective farms or in the industry and there was no time and need to collect NWFPs to earn money. However, collective farms and many industries were closed in 1990s, when the Soviet Union collapsed. At the time of our study, unemployment was high and the forest provided the opportunity to support livelihoods. The majority of respondents pointed out that nowadays the quantity of mushrooms and berries had decreased in the forest. How one respondent said: "The forests have been not managed properly -no silvicultural activity after the harvesting, and the shrubs are all around. There are only a few places to collect berries and mushrooms”.

\section{Småland (Sweden)}

In the Swedish case study, local people harvested NWFPs only for personal use. The villagers collected berries mainly for making pies for immediate use (e.g., blueberry pie). Several respondents also made preserves for own consumption during winter. Chanterelle and funnel chanterelle were collected once or twice per season for immediate cooking. The tradition to hunt and use meat for traditional food like game meat with wild mushrooms was popular in the study area. The hunters mentioned that they got good ecological meat for free. The meat was used for domestic consumption; only one respondent mentioned selling small amounts of meat.

Many respondents stated that collection of berries and mushrooms for food and to sell was important for livelihoods in the region $60-70$ years ago. Even 20 years ago, it was more common to pick different berries and mushrooms for food. The respondents pointed out that, nowadays, one could buy everything in the stores and "at present, other things are more important than picking berries and mushrooms". Among the respondents, people of middle age and older were most interested in harvesting NWFPs, especially if the practice was a tradition in their families and they have lived permanently in the countryside. "My husband's father taught him to hunt. My parents taught me to go to the forest when I was just a couple of years".

The respondents pointed that, after the severe windstorm "Gudrun” in 2005, picking NWFPs and walking in the forest was more difficult due to changed forest 
conditions. The windblown trees damaged the soil, and forestry's use of heavy forest machinery to salvage the timber damaged the vegetation cover. Respondents claimed that as a result the berry and mushroom yields had become reduced during recent years. Intensive forest management was mentioned by the respondents as a reason for decreasing quantities of berries and mushrooms in forests.

\section{Discussion}

\section{Role of national policies for NWFPs}

International policies on SFM state that maintenance and sustainable use of NWFPs are important for rural development and nature resource conservation, especially in forestdependent communities (MCPFE, 2003a; 2007a; 2007b; 2007c). Use of NWFPs can contribute to SFM because it provides tangible economic benefits to rural communities (Ticktin, 2004; Gubbi \& MacMillan, 2008). From a social-cultural perspective, the use of NWFPs has a long tradition in many forested countries and therefore reflects local knowledge and social practices that are worth conserving (Kilchling et. al., 2009). The potential of NWFPs to generate income and jobs could increase with the orientation of society and forest management towards sustainability (Angelstam et al., 2004; Schmithüsen, 2004; Janse \& Ottitsch, 2005; Kilchling et. al., 2009). Social trends towards conserving traditions and using natural medicinal products could support the marketability and profitability of NWFPs (Kilchling et. al., 2009).

Our analyses of national legislation and policies related to NWFPs in Ukraine and Sweden show, however, that there is no clear explanation what kind of resources are included into this category. For example, in Ukraine, NWFPs are considered to be of little importance, a status reflected in their designation as "secondary" forest products. Access to these resources is free. The Forest Code in Ukraine allows collection of NWFPs in all types of forests, except in strictly protected areas (Anon., 2006). The "Right of Public Access" in Sweden provides the opportunity to collect NWFPs, except hunting in any amount on either public or private land. There are some restrictions related to use of Red Book listed species, hunting and harvesting NWFPs in protected areas in both countries. However, there are no requirements or regulations concerning the forest management in order to maintain or protect NWFPs in managed forests. Nor are there any recommendations on how to promote the utilization of NWFPs and develop value-added products from these resources in a sustainable way. At the same time, the international guidelines for SFM promote the use of NWFPs and stress significance of value added products from those resources (MCPFE, 2003a; 2007c).

At present, NWFPs were not included into the forest management plans in our study areas, neither in Ukraine nor in Sweden, which is important for implementing multifunctional and more socially SFM in both countries (Kilchling et al., 2009). Our study shows that NWFPs may provide important resource niches to forest-dependent people, especially in countries with a transition economy. Commercialization and valueadded processing of NWFPs could improve the contribution to household income in Ukraine as a country with a transition economy. Harvesting of NWFPs may find a niche role in development through ecotourism, in which collection activities are regulated and income is largely generated by providing services and valuated products to tourists (Gubbi \& MacMillan, 2008).

In Sweden, NWFPs lost their wide-spread economic meaning during the second half of the $20^{\text {th }}$ century, which also happened in many developed countries in Europe (Kardell, 1980; Kilchling et. al., 2009). Urbanization and economic wealth have since increased the disconnection between people and natural resources. In southern Sweden considerable amounts of lingonberry were exported until about hundred years ago. However, during the past decades foreign citizens and companies exporting berries have 
benefited from the "Right of Public Access" in Sweden. The working immigrants from the former Soviet states, Thailand, Vietnam and other developing countries come to Sweden to pick wild berries, in particular blueberries and lingonberries. In some places, local people claim that tourists and intensive forest management with high basal area, shorter rotation times, use of fertilisers as well as high density of herbivores have led to declining blueberry cover in Sweden and damaged forest ecosystems (Kardell, 1980; Mortazavi, 1997). The Right of Public Access is important for Swedish population who participate in such traditional outdoors activities, while it is to some extent an obstacle to many of the companies building their business on these same activities (Sandell \& Fredman, 2010). There is an opinion that the "Right of Public Access" in Sweden should be reviewed in order to differentiate the collection of NWFPs for personal and commercial purposes (Colby, 1988; Sandell \& Fredman, 2010). To conclude, the multifunctional value of NWFPs provided by forest landscapes has been increasing, but often is neither supported by national policy and management regulations nor appropriate governance (e.g., Laird et al. 2010). At the same time, in some European regions NWFPs and ecosystem services provide more revenue than wood sales (Arnold \& Perez, 2001; MCPFE, 2007a). However, there are challenges to balance production of NWFP and wood, because wood is still economically the most important resource provided by forests. Thus, to promote sustainable use of NWFPs new policy instruments should be developed in both countries.

\section{Different roles of NWFP in rural livelihoods}

This study shows that local populations in forested regions have used NWFPs for domestic and economic purposes for centuries, and continue to do so. At present, the role of NWFPs for local livelihoods is different in Ukraine and Sweden, and this is mainly linked to differences in economic development. Plant and animal NWFPs were used by local forest stakeholders in both study areas. However, in Ukraine, the main group of NWFPs were plant NWFPs, while in Sweden, it was animal NWFPs. In both countries, the NWFPs were used mainly as food, however, in Ukraine selling NWFPs for economic benefit was also important. The utilization of plant NWFPs was more diverse and the amount of harvested NWFPs was much higher per family in Ukraine than in Sweden (Table 1 and 2). The traditional knowledge about the species of NWFPs and how they could be consumed, which have been passed through generations, was also deeper among the Ukrainian villagers. By contrast, hunting was more popular and accepted by Swedish people as a traditional recreation activity, while in Ukraine it was of minor importance.

In Ukraine, NWFPs are used to supplement diets and household income, notably during NWFPs seasons of the year and to help meet medical treatment needs, and these resources are important for subsistence and as an additional income during hard times of transitional economy. Our study indicates that due to social and economic development challenges in countries transitioning from socialistic planned to market economies, forest functions other than wood production have regained local and regional importance. The promotion of value-added products from NWFPs, such as jam, preserved mushrooms and herbal tea could further enhance livelihoods of local people by aggregating more of the products value in the local community. Thus, NWFPs and their value-added processing have potential to support rural livelihoods in developing countries (Ndoye \& Tieguhong, 2004; Gubbi \& MacMillan, 2008).

In Sweden, people are highly appreciative of NWFPs and perceive their use as a civil right, because they do not play a vital role for livelihoods any more. The historical connection to the forest and forest resources is declining. However, promotion of NWFPs use could be a "bridge" between nature and people, especially from urban regions. It has been argued that the potential of NWFPs could be considerably enhanced 
by drawing upon indigenous knowledge and building on the sustainable system of use that local people often seemed to have created (Arnold \& Perez, 2001).

To conclude, improving benefits from use of NWFPs for local rural populations is one of the tasks of SFM. NWFPs provide direct benefit to local people, especially to low income social groups in developing countries like Ukraine. To protect their interests, NWFPs should be included into the multiple-use forest management planning, which has to ensure that timber and NWFPs are managed in a complementary manner. NWFPs trade have the potential to contribution to rural livelihoods (Belcher \& Schreckenberg, 2007).

\section{Acknowledgments}

Funding from the Swedish Institute provided a scholarship to the senior author and covered travel costs in Ukraine, and costs for Swedish field work was covered by grants from Marcus och Amalia Wallenberg Minnesfond. We thank Mikael Angelstam, Robert Axelsson, Sarah Crow, Oksana Prohoretz, Vasyl Rabchuk, and Ruslan Salo for valuable comments and supporting the field study, and all people and organizations that took part in the interviews.

\section{References}

Angelstam, P. \& Elbakidze, M. (2009). Traditional knowledge for sustainable management of forest landscapes in Europe's East and West. In: Soloviy, I.P., Keeton, W.S. (eds.). Ecological Economics and Sustainable Forest Management: Developing a trans-disciplinary approach for the Carpathian Mountains. Ukrainian National Forestry University Press, Lviv, Ukraine, 151-162.

Angelstam, P., Persson, R. \& Schlaepfer, R. (2004). The sustainable forest management vision and biodiversity - barriers and bridges for implementation in actual landscapes. Ecological Bulletins, 51, 29-49.

Anon. (1992). Zakon Ykrainy pro prurodozapovidnui fond Ykrainy. [Law of Ukraine on Nature Protected Areas in Ukraine], 34. (In Ukrainian.)

Anon. (1992/1993). Regeringens proposition. (1992/93). Om en ny skogspolitik [About an new forest policy]. Proposition nummer 226 (In Swedish).

Anon. (1996). Postanova pro zatverdzennya poryadku zagotyvly drugoryadnyh lysovuh materyalyv v lysah Ykrayny. [Resolution approving the harvesting of forest materials and secondary forest products in the forests of Ukraine] Cabinet Ministers, N 449, Kyiv.

Anon. (1997). Skydd av skogsmark - Behov och kostnader. Huvudbetänkande av miljövårdsberedningen. [Protection of forest land - needs and costs. Main Report of the Advisory Council]. SOU 1997:97.

Anon. (1987). Jaktlag. [ Hunting law]. Svensk författningssamling 259

Anon. (2000). Zakon Ykrainy pro myslyvske gospodarstvo ta polyuvannya. [Law of Ukraine on hunting regulation] Vidomosti Verhovnoi Radu, N 18, pp.132. (In Ukrainian.)

Anon. (2004). Press-sluzba derzavnogo komitetu lysovogo gospodarstva Ukrainy.

[Press Service of the State Forestry Committee of Ukraine]. Retrieved March, 17, 2010, from

http://www.kmu.gov.ua/control/uk/publish/printable_article?art_id=8928993

Anon. (2006). Lisovyi kodeks Ykrainy. [Forestry Code of Ukraine]. (In Ukrainian.)

Anon. (2007/2008). Regeringens proposition (2007/08). En skogspolitik i takt med tiden

[A forest policy in line with the times]. Proposition nummer 108. (In Swedish).

Anon. (2008a). Sustainable forest management in the Pan-European region achievements, challenges and planned actions in relation to issues to be addressed at UNFF8. Pan-European contribution to the Eighth Session of the United Nation Forum on Forests. November, 2008. 
Anon. (2008b). Statystuka Yavorivskogo rayina. [Statistic of the Yavoriv district] Yavoriv. (In Ukrainian.)

Anon. (2009). Programa Lisy Ykrainy 2010 - 2015. [On State Programme Forests of Ukraine 2010-2015], 16.09.09 № 977 (In Ukrainian.)

Arnold, M. \& Ruiz-Perez M. (2001). Analysis. Can non-timber forest products match tropical forest conservation and development objectives? Ecological Economics, 39, 437-447.

Belcher, B. \& Schreckenberg, K. (2007). Comercialisation of non-timber forests products: a reality check. Development Policy Review, 25(3), 355-377.

Berglund, B., Lagerås, P. \& Regnell, J. (2002). Odlingslandskapets historia i Sydsverige: en pollenanalytisk syntes. [Agricultural landscape history in South Sweden: a pollen analytical synthesis.] Markens minnen landskap och odlingshistoria på småländska höglandet under 6000 År (eds B.E. Berglund \& K. Börjesson), 153-174. Riksantikvarieämbetet, Stockholm. (In Swedish.)

Bihun, Y. (2005). Principles of Sustainable Forest Management in the Framework of Regional Economic Development. Vistnyk Lvivs'kogo Unviversytetu. Seria Geografichna, 32, 19-32.

Björkman, L. (1996). Long-term population dynamics of Fagus sylvatica at the northern limits of its distribution in southern Sweden: a palaeoecological study The Holocene June 1996 6, 225-234.

Boström, A. (2002). Informal learning in a formal context: Problematizing the concept of social capital in a contemporary Swedish context. International Journal of Lifelong Education, 21(6), 510-524.

Bradshaw, R., Björse, G. \& Holmqvist, B. (2000). Från lövskog till barrskog på 3000 år - människans inflytande på biologisk mångfald i sydsvensk skog idag. [From deciduous to evergreen forests of 3,000 years - human impact on biodiversity in the southern Swedish forests today.] Skog och Forskning nr 1/2000, Sveriges Skogsvårdsförbunds Förlag, Stockholm, 12-17. (In Swedish)

Bryden, J. \& Hart, J. (2004). (eds.). A new approach to rural development in Europe. Germany, Greece, Scotland and Sweden. The Edwin Mellen Press, New York.

Campos, A.J.J., Villalobos R. \& Louman B. (2005). Poor farmers and fragmented forests in Central America. In J.A. Sayer, S. Maginnius (eds). Forests in Landscapes. Ecosystem approaches to sustainability. 129-147. Earthscan, London, Sterling, VA.

Chandrasekharan, C. (1993) Issues involved in the sustainable development of nonwood forest products. FAO. FAO/Commonwealth Science Council Regional Expert Consultation Meeting on Non-Wood Forest Products, Arusha (Tanzania), 17-22 Oct 1993, 27.

Chandrasekharan, C. (1995). Terminology, definition and classification of forest products other than wood. FAO Forestry Department

Colby, K. (1988). Public access to private land - Allemansrätt in Sweden. Landscape and Urban Planning, 15 (3-4), 253-264.

Elbakidze, M. \& Angelstam, P. (2007). Implementing sustainable forest management in Ukraine's Carpathian Mountains: The role of traditional village systems. Forest Ecology and Management, 249, 28-38.

Elbakidze, M. \& Angelstam, P. (2009). Role of traditional village systems for sustainable forest landscapes: a case study in the Ukrainian Carpathian Mountains. In: Soloviy, I.P., Keeton, W.S. (eds.). Ecological Economics and Sustainable Forest Management: Developing a trans-disciplinary approach for the Carpathian Mountains. Ukrainian National Forestry University Press, Lviv, Ukraine, 301316. 
Enander, K. (2007). Skogsbruk på samhällets villkor - skogsskötsel och politik under 150 år. [Forestry according to societal conditions - forest management and policy over 150 years.] Swedish University of Agricultural Sciences, Department of forest ecology and management, report 1, Umeå. (In Swedish.)

Eriksson, S. \& Hammer, M. (2006). The challenge of combining timber production and biodiversity conservation for long-term ecosystem functioning: a case study of Swedish boreal forestry. Forest Ecology and Management 237(1-3), 208-217.

FAO, (1999).Towards a harmonized definition of non-wood forest products. Unasylva 198, 63-64.

FAO, (2002). Non-Wood Forest Products. Retrieved December 10, 2010, from http://www.fao.org/forestry/FOP/FOPW/NWFP

Glasser, B. \& Strauss, A. (1967). (reprinted in 2008) The discovery of grounded theory: strategies for qualitative research. Aldine Transaction, New Bruinswick and London.

Godoy, R., Wilkie, D., Overman, H., Cubas, A., Cubas, G., Demmer, J., et al. (2000). Valuation of consumption and sale of forest goods from a Central American rain forest. Nature, Vol. 406, 62-63.

Government Offices of Sweden. (2008). Rural Development Programme for Sweden the period 2007-2013. Swedish Ministry of Agriculture, Stockholm.

Gubbi, S. \& MacMillan, D. (2008). Can non-timber forest products solve livelihood problems? A case study from Periyar Tiger Reserve, India. Fauna and Flora International, Oryx, 42(2), 222-228.

Hagner, S. (2005). Skog i förändring - vägen mot ett rationellt och hållbart skogsbruk i Norrland 1940-1990. [Changing forest - the road toward a rational and sustainable forestry in Norrland 1940-1990] Kungliga skogs och lantbruksakademien, Stockholm. (In Swedish.)

Hyde, W. \& Köhlin, G. (2000). Social forestry reconsidered. Silva Fennica, 34 (3), $285-314$.

ITTO, (2005). International tropic timber organization. Status of tropical management report. Retrieved February 23, 2010, from http://www.itto.int/sfm/

Janse, G. \& Ottitsch, A. (2005). Factors influencing the role of Non-Wood Forest Products and Services. Forest Policy and Economics, 7, 309- 319.

Johansson, L. (1999). Landen kring sjöarna. En historia om Kronobergs län i måntusenårigt perspektiv. [The lands around the lakes. A history of Kronoberg County with thousand year perspective] Grafiska punkten, Växjö. (In Swedish.)

Källberg, A. (2007). På resa genom turistbroschyrernas Småland. [Traveling through the tourist brochures of Småland] Högskolan i Kalmar. (In Swedish.)

Kardell, L. (1980). Forest berries and mushrooms: an endangered resource? Ambio, vol. 9, No. 5, 241-247

Kilchling, P., Hansmann, R. \& Seeland, K. (2009). Demand for non-timber forest products: survey of urban consumers and sellers in Switzerland, Forest Policy and Economics, 11, 294-300.

Komendar, V. (1971). Lykarsky roslyny Karpat. [Medical herbs of the Carpathians]. Uzhgorod, 248. (In Ukrainian.)

Kruglyakov, G. (1991). Zagogtovky, hranenyia y pererabotka dykorastuschyh yagod y grybov. [Harvesting, storage and processing of wild berries and mushrooms]. Moscow, 159. (In Russian.)

Kvale, S. \& Brinkman, S. (2008). InterViews: Learning the craft of qualitative research interviewing. Sage publications, Thousand Oaks.

Kvale, S. (2007). Doing interviews. Sage publications, London. 
Lagerås, P. (1996). Vegetation and land-use in the Småland Uplands, southern Sweden, during the last 6000 years. PhD thesis. Department of Quaternary Geology, Lund University.

Lagerås, P. (2007). The ecology of expansion and abandonment. Medieval and postmedieval land-use and settlement dynamics in a landscape perspective.

Stockholm: Riksantikvarieämbetet.

Laird, S.A., McLain, R. \& Wynberg, R.P. (eds.) (2010). Wild product governance: finding policies that work for non-timber forest products. Earthscale, London, United Kingdom, 393 p.

Løyche Wilchie, M., Holmgren P. \& Castaneda, F. (2003). Sustainable forest management and the ecosystem approach. Working paper FM 25. FAO, Rome.

Malyk, L. (2006). Modern consisting and problems of the use of non-wood forest resources of western region of Ukraine. Lviv, Naukovyu visnyk 16.5, 42-44. (in Ukrainian).

McDonald, G. \& Lane, M. (2004). Converging global indicators for sustainable forest management. Forest Policy and Economics 6, 63-70.

MCPFE (1993). Resolution H1General Guidelines for the Sustainable Management of Forests in Europe. Second Ministerial Conference on the Protection of Forests in Europe 16-17 June 1993, Helsinki, Finland. 5p. Retrieved February 22, 2010, from http://www.mcpfe.org

MCPFE (1995). Pan-European Criteria and Indicators for Sustainable Forest Management. Annex 1 of the Resolution 1, Lisbon, Vienna Liaison Unit. Retrieved February 22, 2010, from http://www.mcpfe.org

MCPFE, (1998a). Annex 1 of the Resolution L2 Pan-European Criteria and Indicators for Sustainable Forest Management. Third Ministerial Conference on the Protection of Forests in Europe. 2-4 June 1998, Lisbon/Portugal 14p.

MCPFE, (1998b). Resolution L1. People, Forests and Forestry -Enhancement of SocioEconomic Aspects of Sustainable Forest Management. Third Ministerial Conference on the Protection of Forests in Europe. 2-4 June 1998, Lisbon/Portugal 4p.

MCPFE, (2001). Criteria and indicators for sustainable forest management of the MCPFE. International expert meeting on monitoring, assessment and reporting on the progress towards Sustainable Forest Management 5-8 November 2001, Yokohama, Japan. 13p. Retrieved February 22, 2010, from http://www.mcpfe.org

MCPFE, (2003a). State of Europe's Forest; Fourth Ministerial Conference on the Protection of Forests in Europe, 28-30 April 2003.- Liaison Unit, Vienna. Retrieved February 22, 2010, from http://www.mcpfe.org

MCPFE, (2003b). Documents adopted at the Fourth Ministerial Conference on the Protection of Forests in Europe, 28-30 April 2003, Liaison Unit, Vienna.

Retrieved February 22, 2010, from http://www.mcpfe.org

MCPFE (2007a). Fifth Ministerial Conference on the Protection of Forests in Europe. Conference Proceedings, 5-7 November 2007, Warsaw, Poland, 272. Retrieved February 22, 2010, from http:// www.mcpfe.org

MCPFE (2007b). Implementation of MCPFE commitments National and Pan-European Activities 2003 - 2007 Ministerial Conference on the Protection of Forests in Europe, 99. Retrieved February 22, 2010, from http://www.mcpfe.org

MCPFE (2007c). State Of Europe's Forests 2007. The MCPFE report on sustainable forest management in Europe. Ministerial Conference on the Protection of Forests in Europe, Liaison Unit Warsaw, 247. Retrieved February 22, 2010, from http://www.mcpfe.org

Mortazavi, R. (1997). The right of public access in Sweden. Annals of Tourism Research, Vol. 24, No. 3, 609-623. 
Ndoye, O. \& Tieguhong, J. (2004). Forest resources and rural livelihoods: the conflict between timber and nontimber forest products in the Congo Basin. Scandinavian Journal of Forest Research 19 (Suppl. 4), 1-9.

Nijnik, M. \& Oskam, A. (2004). Governance in Ukrainian forestry: trends, impacts and remedies. In: Agricultural Resour Gov Ecology 3, 116-133.

Nijnik, M. \& van Kooten, C.G. (2006). Forestry in the Ukraine: the road ahead? Reply. Forest Policy and Economics, 8(1), 6-9.

Nordmark, H. (ed.) (1997). Kulturbilder från småländskt 1700-tal. [Cultural images from Småland 1700.] Historiska föreningens i Kronobergs län skriftserie 7. (In Swedish.)

Nordström, O., Larsson, L., Käll, J. \& Larsson, L.O. (1989). Skogen och smålänningen. Kring skogsmarkens roll i förindustriell tid. [The forest and the Smålander. About the role of forest lands in pre-industrial times.] Historiska föreningens i Kronobergs län skriftserie 6. (In Swedish.)

Petrova, V. (1986). Byohymyya dykorastushchyh plodovo-yagodnyh rastenyj. [Biochemistry of wild berries plants.] Kiev, 287. (In Ukrainian.)

Rametsteiner, E. \& Mayer, P. (2004). Sustainable forest management and Pan-European forest policy. - Ecological Bulletin 51, 51-57.

Red Data Book of Ukraine. (2009). Chervona knyga Ukrainy. Tvarynnyi svit. [Red Data Book of Ukraine] Kiev, Globalconsalting, 600. (In Ukrainian.)

Ryabchuk, V. (1996). Nederevni resursy lisy. [Non-wood forest resources]. Lviv, 312. (In Ukrainian.)

Ryen, A. (2004). Kvalitativ intervju.[Qualitative interviews] Liber, Malmö. (In Swedish).

Saastamoinen, O. (1999). Forest policies, access rights and non-wood forest products in northern Europe. Unasylva 50 (198), 20-26.

Saastamoinen, O., Kangas, K. \& Aho, H. (2000). The picking of wild berries in Finland in 1997 and 1998. Scandinavian Journal of Forest Research, 15: 6, 645 - 650

Sandell, K. \& Fredman, P. (2010). The Right of Public Access - Opportunity or Obstacle for Nature Tourism in Sweden? Scandinavian Journal of Hospitality and Tourism, 10: 3, $291-309$.

Schmithüsen, F. (2004). European Forest Policy Developments in Changing Societies: Political Trends and Challenges to Research. EFI Proceedings No. 49: 87-99, Joensuu/Finland, European Forest Institute.

Statistics Sweden. (2011). Statistical Yearbook of Sweden. Statistics Sweden, Stockholm.

Stryamets, G. \& Danchuk, O. (2007). Landshaftne ta biologichne riznomanittya ukrajnskoi chastyny biosfernogo rezervatu. [Landscape and biological diversity of the Ukrainian part of the Biosphere Reserve "Roztochya”]. Lisove ta myslyvske gospodarstvo. Zytomyr, 71-76. (In Ukrainian).

Stryamets, G. \& Ferenc, N. (1999). Osoblyvosti rostu introdukovanyh derevnyh vudiv u zapovydnuh umovah. [Features of growth of introduced tree species in a protected environment.] Visnyk Lysotehnychnogo universytetu 9.9, 244 - 250. (In Ukrainian).

Swedish Environmental Protection Agency (2005). The Environmental Code. Retrieved March, 17, 2010, from http://www.swedishepa.se/en

Swedish Environmental Protection Agency (2009). Nature conservation and wildlife management. Retrieved March, 17, 2010, from http://www.swedishepa.se/en

Swedish Forestry Act, (1979). Skogsvåtrdslag, SFS 1979:429, Stockholm, Sweden, 5 pp. (In Swedish.) 
Swedish Forestry Act, (1993), Lag om ändring i skogsvårdslagen [Law about changes in the forestry act] (SFS 1979:429), SFS 1993:553, Stockholm, Sweden, 9 pp. (In Swedish.)

Telishevskyy, D. (1972). Grybu, yagidnyky ta likarsky roslyny lisiv Ukrainy. [Mushrooms, berries and herbs of forests in Ukraine. Biological features and methods of accounting.] Lviv. (In Ukrainian.)

Terletskyy, V. (1985). Nezamenymye produkty lesa. [Irreplaceable Forest Products.].Lviv High School-publishing house in Lviv, 128. (In Ukrainian.)

The Economist. (2010). Democracy index 2010. Democracy in retreat. The Economist intelligence unit.

The Montréal Process (2007). Criteria and indicators for the conservation and sustainable management of temperate and boreal forests. Third Edition. Retrieved March, 11, 2010, from http://www.rinya.maff.go.jp/mpci/

The Swedish Forest Agency. (2010). Skogsstatistik årsbok. [Forest statistic yearbook] Skogsstyrelsen, Jönköping. (In Swedish.)

Ticktin, T. (2004). The ecological implications of harvesting non-timber forest products. Journal of Applied Ecology 41, 11-21

UNCED, (1992). Report of the United Nations Conference on environment and development, Rio de Janeiro, 3-14 June 1992.

Wong, J., Thornber, K. \& Baker, N. (2001). Resource assessment of non-wood forest products. Experience and biometric principles. Food and agriculture organization of the United Nations, Rome.

Yelin, Y., Zerov, M., Lushpa, V. \& Shabarova, S. (1987). Daru lysyv. [Gifts of the forests] $4^{\text {th }}$ ed., Kyiv, Urozaj, 304. (In Ukrainian.)

Zinnbauer, D., Dobson, R. \& Despota, K. (2009). Global corruption report 2009. Corruption and the private sector. Transparency International, Cambridge University Press, Ernst and Young. 